Економічні науки: збірник наукових праць Луиького національного технічного університету. Серія "Регіональна економіка". Випуск 17 (67). Редкол.: відп. ред. к.е.н., професор І.В. Кривов’язюк. Луиьк: ІВВ Луцького НТУ, 2020. 348 с.

УДК 330.341 .30

Павлюк Л.В., к.е.н., доцент

Луцький національний технічний університет

\title{
ВАЖЛИВІСТЬ БІЗНЕС-ПЛАНУВАННЯ ПРИ ПРИЙНЯТТІ УПРАВЛІНСКИХ РІШЕНЬ
}

У науковій публікації розглядаються питання важливості здійснення процесу планування та бізнес-планування при прийнятті управлінських рішень для підвищення ефективності господарювання підприємства.

Ключові слова: бізнес-планування, управлінські рішення, бізнеспроєкт, бізнес-план, виробничо-господарська діяльність, ефективність господарювання.

Pavliuk L.

\section{THE IMPORTANCE OF BUSINESS PLANNING IN MAKING MANAGEMENT DECISIONS}

This scientific work addresses the importance of the implementation of the planning process and business planning in accepting management decisions to improve the efficiency of the enterprise. The main purpose of the business plan is to convince future investors that the business project has a strategy of success and deserves the financial support. The business plan helps the CEO of the enterprise to 
Економічні науки: збірник наукових праць Луиького національного технічного університету. Серія "Регіональна економіка". Випуск 17 (67). Редкол.: відп. ред. к.е.н., професор І.В. Кривов’язюк. Луцьк: ІВВ Луцького НТУ, 2020. 348 с.

make the appropriate decision on the feasibility or inexpediency of making a business project. This is a practically a working tool used in all areas of entrepreneurship and serves as an effective tool in making management decisions.

The main feature of the management decision is a focus on solving the goals and objectives of the enterprise. It should be noted that the management decision is made only by the CEO of the enterprise or the board of directors. The success of the enterprise depends on the timeliness of management decisions. So, the management decision is a choice of one among alternative decisions; it is a solution that will help to achieve the goals of the enterprise and increase the efficiency of its activities.

The business planning process also pursues similar goals. In modern business conditions, the main tasks of business planning: real and timely assessment of business ideas; establishing the quantitative value of resources, necessary costs and sources of funding; optimal choice of strategy of the enterprise on which the business plan is realized; search for reliable partners and contractors for the implementation of the business plan; assessment of the competitive environment; identification of levels and types of risks that may arise during project implementation and development of methods to reduce them; assistance in management decisions; forecast of the future results, etc.

At the preparatory stage of the business planning process, the necessary information is collected, analyzed, and the strengths and weaknesses of the enterprise, which provides for the implementation of the business project. At the same stage, the positive and negative influence of external factors, the formation of general goals of the business project, as well as outlining ways, methods and means to achieve them.

In turn, the business plan is a document developed on the basis of the analysis of internal and external environment. It formulates the essence of business ideas, available tools, effective methods and tools for its implementation, as well as calculated rates of return on investment and efficiency of investment, possible risks, expected results, consequences and prospects of business development. All these calculated parameters greatly help to make a balanced and correct management decision.

It is clear that the successful development of the market system in our country requires the latest approaches to management decisions, as well as the management of economic activity in general and entrepreneurial activity. Therefore, the successful implementation of a particular business project becomes impossible without a prior process of business planning and development of a detailed business plan.

So, as a result, it can be argued that those companies that seek to effectively develop their business must develop a detailed business plan that will show the effectiveness of creating a new product or service, the implementation of which will lead to additional profits. Therefore, the use of a business plan in making management decisions regarding the introduction of a new type of product, changes in the volume of manufactured products, changes in technology, improving product quality or a number of other production problems will be a quality tool to solve these problems. 
Економічні науки: збірник наукових праць Луиького національного технічного університету. Серія "Регіональна економіка". Випуск 17 (67). Редкол.: відп. ред. к.е.н., професор І.В. Кривов’язюк. Луцьк: ІВВ Луцького НТУ, 2020. 348 с.

Key words: business planning, management decisions, business project, business plan, production and economic activity, management efficiency.

Павлюк Л.В.

\section{ВАЖНОСТЬ БИЗНЕС-ПЛАНИРОВАНИЯ ПРИ ПРИНЯТИИ УПРАВЛЕНЧЕСКИХ РЕШЕНИЙ}

В научной публикации рассмотрены вопросы важности процесса планирования и бизнес-планирования при принятии управленческих решений для повышения єффективности деятельности предприятия.

Ключевые слова: бизнес-планирование, управленческие решения, бизнес-проект, бизнес-план, производственно-хозяйственная деятельность, эффективность хозяйствования.

Постановка проблеми у загальному вигляді і її зв'язок 3 важливими науковими та практичними завданнями.

На сучасних підприємствах надважливою задачею $\epsilon$ проблема прийняття вчасних та правильних управлінських рішень задля успішного та ефективного господарювання. Для цього необхідно здійснювати процес планування в цілому та бізнес-планування зокрема, яке передбачає розробку та впровадження бізнес-плану. Це надзвичайно важливо, адже у сучасних умовах, планування та бізнес-планування є одним із найбільш ефективних інструментів управління, яке успішно допомагає при прийнятті управлінських рішень.

Аналіз останніх досліджень, у яких започатковано вирішення проблеми. Питанням бізнес-планування та розробці і впровадженню бізнес-плану присвятили свої наукові праці багато українських та зарубіжних учених, а саме: Г. Бірман, I. Бланк, В. Бочаров, Л. Гітман, А. Загородній, В. Захарченко, А. Маршалл, І. Мейо, А. Пересада, В. Пономаренко, К. Рейлі, Р. Холт, В. Царьов, С. Четиркін, В. Шеремет та інші дослідники.

У той же час, важливий внесок в теорію важливості планування при прийнятті управлінських рішень зробили такі учені, як: О.І. Амоша, В.М. Геєць, Г.К. Губерна, О.С. Поважний, O.М. Теліженко, О.I. Черняк, 3.С. Шершньова та ін.

Однак, незважаючи на підвищений інтерес до цієї надважливої проблеми, багато іiі аспектів залишаються 
Економічні науки: збірник наукових праць Луиького національного технічного університету. Серія "Регіональна економіка". Випуск 17 (67). Редкол.: відп. ред. к.е.н., професор І.В. Кривов'язюк. Луиьк: ІВВ Луцького НТУ, 2020. 348 с.

недостатньо висвітленими та потребують подальшого дослідження.

Цілі статті. Головною ціллю наукової статті $\epsilon$ дослідження важливості бізнес-планування при прийнятті управлінських рішень у господарській діяльності підприємств задля підвищення ефективності їх господарювання.

Виклад основного матеріалу дослідження 3 повним обгрунтуванням отриманих наукових результатів.

Нині, для сучасних підприємств важливою проблемою $є$ підвищення ефективності їх діяльності. Для цього необхідно проводити процес бізнес-планування, який передбачає розробку та впровадження бізнес-плану.

У свою чергу, бізнес-план це певний документ, який розробляється 3 метою залучення необхідних фінансових ресурсів. Головним призначенням бізнес-плану $є$ переконання майбутніх інвесторів у тому, що бізнес-проєкт має свою мету, стратегію успіху та заслуговує на фінансовий супровід та підтримку. Тобто, бізнес-план фактично допомагає керівнику підприємства прийняти відповідне рішення про доцільність чи недоцільність прийняття бізнес-проєкту та виступає практично робочим інструментом, що використовується в усіх сферах підприємництва і слугує дієвим інструментом при прийнятті управлінського рішення. Його розробляють у випадку створення нового бізнесу чи організації нового підприємства; при об'єднанні існуючих підприємств або зміні власності; при започаткуванні зовнішньоекономічної діяльності або ж при освоєнні нових ринків тощо [1, с. 192-199].

В той же час, в науковій літературі термін «управлінське рішення» найчастіше вживається в таких значеннях:

- намір зробити певну дію, яка передбачає попереднє усвідомлення цілей;

- усвідомлений процес вибору найкращого варіанту (альтернативи) для вирішення певної проблеми;

- фіксована управлінська дія, направлена на результат.

Головною ознакою управлінського рішення $\epsilon$ його спрямованість на вирішення цілей та мети підприємства. Варто 
Економічні науки: збірник наукових праць Луиького національного технічного університету. Серія "Регіональна економіка". Випуск 17 (67). Редкол.: відп. ред. к.е.н., професор І.В. Кривов'язюк. Луиьк: ІВВ Луцького НТУ, 2020. 348 с.

зазначити, що управлінське рішення приймається лише керівником підприємства чи радою директорів.

Від вчасності прийняття управлінського рішення залежить успішність роботи підприємства. Отож, управлінське рішення це вибір одного варіанту серед альтернативних варіантів; це рішення, що допоможе досягти мети підприємства та підвищити ефективність його діяльності.

Процес бізнес-планування також переслідує подібні цілі. В сучасних умовах ведення господарської діяльності, до головних завдань бізнес-планування можна віднести:

- реальну та своєчасну оцінку бізнес-ідеї;

- встановлення кількісної величини ресурсів, необхідних витрат та джерел фінансування;

- оптимальний вибір стратегії підприємства, на якому реалізується бізнес-план;

- пошук надійних партнерів та контрагентів для впровадження бізнес-плану;

- оцінка конкурентного середовища;

- визначення рівнів та видів ризиків, які можуть виникнути під час реалізації проєкту та розробка методів їх зниження;

- допомога в прийнятті управлінського рішення;

- прогноз майбутніх результатів тощо.

Зрозуміло, що успішний розвиток ринкової системи в нашій державі потребує новітніх підходів як до прийняття управлінських рішень, так i до управління господарською діяльністю в цілому та підприємницькою діяльністю зокрема. Тому, вдала реалізація певного бізнес-проєкту стає неможливою без попередньо здійсненого процесу бізнес-планування та розробки детального бізнес-плану. Цей документ $є$ в деякій мірі гарантом необхідного фінансування для успішного ведення бізнесу.

На підготовчому етапі процесу бізнес-планування збирається необхідна інформація, проводиться іiі аналіз, встановлюються сильні та слабкі сторони підприємства, на якому передбачається реалізація бізнес-проєкту. На цьому ж 
Економічні науки: збірник наукових праць Луиького національного технічного університету. Серія "Регіональна економіка". Випуск 17 (67). Редкол.: відп. ред. к.е.н., професор І.В. Кривов’язюк. Луцьк: ІВВ Луцького НТУ, 2020. 348 с.

етапі виявляють позитивний та негативний вплив зовнішніх чинників, формування генеральних цілей реалізації бізнеспроєкту, а також окреслення шляхів, методів та засобів їх досягнення. На рис. 1 подано загальну схему здійснення підготовчого етапу процесу бізнес-планування на підприємстві.

Загальна характеристика підприємства та аналіз його виробничогосподарської діяльності

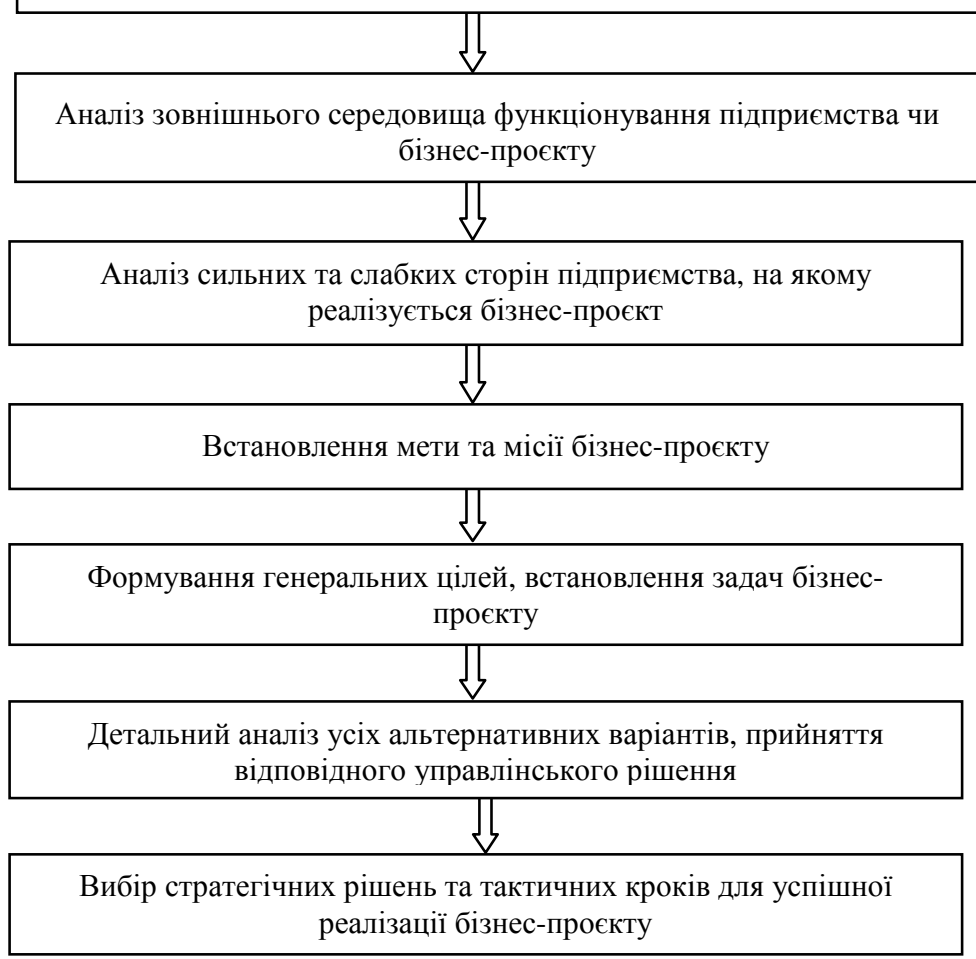

Рис. 1. Схема здійснення підготовчого етапу процесу бізнес-планування на підприємстві

У свою чергу, бізнес-план - це документ, що розроблений на основі аналізу внутрішнього та зовнішнього середовища 
Економічні науки: збірник наукових праць Луиького національного технічного університету. Серія "Регіональна економіка". Випуск 17 (67). Редкол.: відп. ред. к.е.н., професор І.В. Кривов'язюк. Луиьк: ІВВ Луцького НТУ, 2020. 348 с.

функціонування підприємства. У ньому сформульована сутність бізнес-ідеї, наявні засоби, дієві методи та інструменти іiі реалізації, а також розраховані показники окупності та ефективності вкладення капіталу, можливі ризики, очікувані результати, наслідки та перспективи розвитку бізнесу. Усі ці розраховані параметри в значній мірі допомагають прийняти виважене та правильне управлінське рішення.

Грунтовно розроблений бізнес-план $€$ важливим інструментом, що використовується у процесі переговорів 3 інвесторами. В той же час, він відіграє важливу роль у підборі на роботу кваліфікованих фахівців, його використовують для залучення надійних партнерів чи кредиторів.

Бізнес-планування $€$ однією 3 важливих складових системи фінансового планування на підприємствах, які функціонують в умовах конкурентного середовища, оскільки воно не лише забезпечує внутрішні потреби підприємства в обгрунтованих кількісних оцінках майбутніх капіталовкладень, а й сприяє залученню надійних інвесторів для їх фінансування [2].

Як правило, процес бізнес-планування охоплює період від трьох до п'яти років, тому воно може перекликатися 3 стратегічним плануванням. Але, на противагу від останнього, процес бізнес-планування охоплює не усі цілі підприємства, а лише ті, що пов'язані 3 створенням чи розвитком нового бізнесу. Ці цілі мають чітко встановлені часові межі, після закінчення яких в обов'язковому порядку повинні бути виконаними. Окрім того, в бізнес-плануванні такі його функціональні складові, як план виробництва, маркетингові рішення, юридичний план, мають набагато важливіше значення, ніж при стратегічному плануванні та $\epsilon$ обов'язковими структурними розділами бізнес-плану [3, с. 176].

Що стосується бізнес-плану, то його структура не $\epsilon$ сталою, вона змінюється в залежності від багатьох факторів (призначення бізнес-плану, виду бізнесу, масштабів підприємства, його юридичного статусу та ін.). Здійснимо спробу подати рекомендовану структуру бізне-плану, незалежно 
Економічні науки: збірник наукових праць Луиького національного технічного університету. Серія "Регіональна економіка". Випуск 17 (67). Редкол.: відп. ред. к.е.н., професор І.В. Кривов'язюк. Луиьк: ІВВ Луцького НТУ, 2020. 348 с.

від зовнішніх чи внутрішніх параметрів функціонування підприємства: титульний лист; резюме; аналіз сфери господарювання з описом зовнішніх та внутрішніх чинників, що впливають на діяльність підприємства; оцінка конкурентів та вибір стратегії; план виробництва.

Для плану виробництва чи виробничого плану основним завданням $€$ переконання потенційних партнерів, що підприємство зможе реально виробляти заплановану кількість продукції у необхідні строки. Тут мають бути економічні розрахунки необхідних витрат, опис основних методів виробництва, опис наявної технології, засоби контролю якості, вказана кількість та кваліфікація персоналу тощо.

У той же час, маркетинговий план має висвітлити політику підприємства щодо збуту виготовленої продукції, оптимальної політики цін та ціноутворення, можливих каналів товароруху, подання реклами тощо. Детальний опис таких відомостей допоможе керівникам прийняти виважене управлінське рішення щодо маркетингу.

Натомість, організаційний план повинен містити відомості щодо форми власності підприємства; найбільш оптимальної організаційної структури, способів взаємодії різних рівнів ієрархіï.

Зупинимося більш детально на змісті фінансового плану при процесі бізнес-планування. Саме тут здійснюється детальний фінансовий аналіз підприємства, на якому реалізується бізнес-проєкт. У цьому ж розділі прогнозують нійбільш оптимальні обсяги реалізації продукції чи послуг. Тут же оцінюють інвестиційні витрати та розраховуються поточні витрати; проводиться економічне прогнозування прибутків та прогноз очікуваних грошових потоків, які виникнуть від впровадження проєкту. На цьому ж етапі здійснюється детальний розрахунок показників доцільності впровадження та економічної ефективності бізнес-проєкту 3 оцінкою ризиків [3, с. 183-184]. У цьому ж розділі встановлюються точні терміни вкладення інвестицій та термін їх окупності. 
Економічні науки: збірник наукових праць Луиького національного технічного університету. Серія "Регіональна економіка". Випуск 17 (67). Редкол.: відп. ред. к.е.н., професор І.В. Кривов’язюк. Луцьк: ІВВ Луцького НТУ, 2020. 348 с.

Отож, як підсумок, можна стверджувати, що ті підприємства, які прагнуть ефективно розвивати свій бізнес, мусять розробляти детальний бізнес-план, який буде свідчити про ефективність створення нової продукції чи послуги, реалізація якої призведе до отримання додаткового прибутку підприємством. Тому, використання бізнес-плану при прийнятті управлінських рішень, що стосуються впровадження нового виду продукції, зміни обсягу виготовленої продукції, зміни технології, підвищення якості чи ряду інших виробничих проблем, буде якісним інструментом вирішення цих проблем.

Висновки. Отож, у сучасних умовах господарювання, всі підприємства намагаються здійснювати свою господарську діяльність 3 максимальною прибутковістю при мінімізації витрат, що в кінцевому результаті призведе до підвищення конкурентоспроможності, зростання рентабельності та успішності підприємств. Саме використання процесу бізнеспланування при прийнятті важливих управлінських рішень зможе допомогти вирішити цю надважливу проблему. Причому, розраховані дані можна брати за основу при розробці стратегічних планів розвитку підприємства, при обгрунтуванні оптимальних обсягів виробництва продукції, плануванні прибутковості, рентабельності тощо.

\section{Список бібліографічного опису}

1.Григорчук Т.В. Маркетинг. Частина друга: Навч. посіб. для дистанційного навчання. К.: Університет «Україна», 2007. 300 с.

2.Проектний аналіз. Л.Л. Ковальська, Л.В. Павлюк, Л.В. Савош. Навчальний посібник. Луцьк: РВВ Луцького НТУ, 2014. 264 с.

3.Економіка підприємства : підручник / під. заг. ред. д.е.н., проф. Ковальської Л.Л. та проф. Кривов’язюка І.В. Київ : Видавничий дім «Кондор», 2020. $700 \mathrm{c}$.

\section{References}

1. Grygorchuk T.V. Marketung. Chastuna dryga: Navch.posib. dlya dustanchiynogo navchanna. K. Yniversytet «Ucraina», 2007. $300 \mathrm{p}$.

2. Proektniy analiz. / L.L. Kovalska, L.V. Pavliuk, L.V. Savoch // Navchalniy posibnyk. Lutsk: PVV Lytskogo NTY, 2014. 264 p.

3. Economica pidpriemstva : pidruchnyk / pid. zag. red. d.e.n., prof. Kovalskoiy L.L. ta prof. Kruvovijzyka I.B. Kiyv : Vudavnuchuj dim «Kondor», 2020. $700 \mathrm{p}$. 